\title{
The need to synthesise industry academy ambitions
}

\author{
KERRY GREEN \\ University of Canberra
}

$\mathbf{J}^{\mathrm{o}}$ OURNALISM education in Australia,as it seems in New Zealand, finds itself between a rock and a hard place. On the one hand universities find themselves under pressure to provide courses that meet industry demands and enhance job success rates; on the other hand journalists seek to be recognised as professionals for a wide range of reasons. Among those reasons is the desire to raise the credibility of journalism in the public perception and the need to argue for higher rates of pay and improved conditions.

Can the tension between the twin urges to professionalise and to react to market forces be accommodated in journalism education in Australia? And do those two urges have to be mutually exclusive?

Journalism - in Australia at least — is under pressure to professionalise for two reasons: First, employers believe that credibility is a major issue in the continuing battle to halt the circulation decline; second, journalists themselves perceive the path to greater remuneration lies through professionalisation.

\section{First, the employers}

Australian newspaper publishers, and to a lesser extent television employers, have accepted the findings of the US Newspaper Credibility Project. The American Society of Newspaper Editors (ASNE), concerned about the continuing circulation plunge, instituted the Newspaper Credibility Project. In its report (1999), it had this to say:

The American Society of Newspaper Editors' Journalism Credibility 
Project, launched in 1997, sought to better understand reasons for the decline in public confidence, to strengthen industry commitment to improvement and to test methods for addressing public concerns about newspaper accuracy, fairness and values. So far, the lesson of the project has been that newspapers can do something about their credibility with the public. The problem is not just the result of abuses by other media or general public distrust of institutions.

The project recommended three courses of action:

- That newspapers improve their journalism. Much public dissatisfaction results from journalism's failure to live up to public expectations - and to the newspaper profession's own stated standards - whether it's for accuracy, avoiding sensationalism, restricting use of anonymous sources or a commitment to fairness.

- That newspapers do a better job of showing the public that they are trying to make decisions that reflect journalism's core values and to give weight in their journalistic deliberation to ideas and challenging questions from the public.

- That newspapers better define their place in a confusing and rapidly changing media universe, a process that will require creativity to avoid sacrificing core journalistic goals.

Happily, the society is calling for higher standards of journalism from its practitioners in an attempt to reverse circulation trends. The commitment to 'core journalistic goals' and to 'journalism's core value' is an important public acknowledgement of journalism's Fourth Estate function and the need for ideals that will stand up to public scrutiny. This commitment is reflected in the proliferation of codes of ethics and codes of practice in US newsrooms, as the industry struggles to achieve an accommodation between journalistic notions of fairness and public ideals.

While Australian newspapers also battle plunging circulations and television stations grapple with dwindling audiences, their employees are involved in a battle of their own. Periodically, The Bulletin magazine pays a polling organisation to assess the public status of a variety of occupations. Invariably, journalism rates poorly. The Morgan Gallup polls provide evidence of the low standing of journalists in the opinion of the Australian population. For example, in 2000 , only 12 per cent of respondents nominated television reporters and seven per cent nominated newspaper journalists as having high or very high standards of ethics and honesty. Overall, newspaper journalists were rated 27 th 
out of the 28 occupational groups studied that year in terms of perceived ethics and honesty, and the only occupation to score lower than newspaper journalists was used-car salesmen (Roy Morgan, 2000). Australian sociologist Daniel notes $(1990,102)$ :

The influence of the media penetrates every aspect of social, political and cultural life ... The media's reputation for pervasive and persuasive influence is too well heralded to dispute. Given this context, the prestige of journalists, editors, and related workers appears somewhat lower than might be expected.

Just as the standing of journalists is low in the eyes of the public, so are the pay rates of journalists in the eyes of employers. The rates of pay for journalists in Australia, for example, where a J1 earns about $\$ A 35,000$, do not match the rates for professionals like doctors, lawyers, teachers, engineers. Yet journalists could argue that the work they perform is every bit as vital to the efficient operation of society and indeed, if we look at neoclassical economic theory, one of the pillars of efficient market operation is the requirement for information on which rational consumer decisions can be based. Only the mass media is capable of providing such information.

So the work of journalists is important. But I am reminded of a reaction from a newspaper general manager, back in the dim dark ages when I was a newspaper editor. He was a member of an industry award negotiating team and he would regularly return from meetings with union officials crowing about how dumb journalists were: 'You only have to say to them that anyone can be a journalist - you don't need any qualifications to be a journalist — and they always agree. Once they do that, you can beat them around the head with their wage demands.'

\section{Journalists' attitudes changing}

I believe journalists' attitudes are changing, at least in Australia. Journalists now realise they must be able to point to qualifications that are recognized throughout the industry and that is why the JEA's move towards accreditation is receiving strong support from within industry. As the various elements of the news media have come to understand that a lack of credibility has economic, as well as social, outcomes they have cast about for ways to improve performance, and the Journalism Credibility Project is just one reaction.

In Australia, researchers have argued that another way to improve the 
credibility of journalists and journalism - and hence the quality of information disseminated — is to improve their education (Daniel 1990; Henningham 1988, 1990; Smyth \& Lawe Davies, 1990; Morgan 2000). But the move towards a better educated, more professionalised journalism industry itself raises a number of issues, some of which have been discussed in journalism education forums over the years. In particular, some journalism practitioners argue that to perform the Fourth Estate function — to be society's watchdog — it is necessary to revert to the muckraker function of journalism and that a low level of respectability is almost a sine qua non. However, I believe academics like Henningham voice the majority opinion when they call for greater professionalisation of the industry. Henningham (1990: 154), indeed, brings together the industry's and the profession's motives for professionalisation into a benefit for society as a whole. He underscores the value to society of properly educated journalists when he says:

For the public, a better educated, more job-secure and more independent profession of journalism should yield a news product that is more credible, more reliable and is capable of providing a deeper, multi-facted representation of the truth.

If publishers and their employees are convinced, then, that their survival depends upon a more professional and better-educated cadre of journalists, what form should the education take? If employers are to rely upon the academy, how can they know which journalism courses include the kind of skills relevant to industry and, perhaps even more importantly, to particular sections (print, radio, television, online) of the mass media? Just as importantly, from a societal point of view, how can educators include course content that may be essential to a journalist's understanding of the profession and/or society in general, but not necessarily essential to the process of news publishing? In Australia, the issue is characterised by debate around the difference between journalism-specific courses and media studies courses concentrating on study of the mass mediaoften from a cultural studies perspective: employers want graduates from the former and shun graduates from the latter.

This article does not enter into the debate about the relative merits of either course of study, but the very existence of the debate indicates the problems that arise when employers confuse one kind of course with the other. Clearly, accrediting courses would eliminate the confusion. But even within the ranks of 
journalism-specific courses, there is a perception that some are industryacceptable and others are not, based on the subjective assessments of employers. This was particularly evident in the debate on ABC Radio National's Media Report programme (7 June 2001: www.abc.net.au/rn/talks/8.30/mediarpt/stories/ s309511.htm) in which journalism programmes given de facto industry 'approval' were listed and the problem of admixtures with media studies and cultural studies at others was raised.

Journalism education, if it is to benefit society, needs to move away from a system in which there is no formal connection between the academy and industry, and in which one does not inform the other of what each believes to be useful and desirable in the education of journalists. It needs to move towards a system which acknowledges the existence of the relationship but which does not empower either party to the detriment of the news media's service to society in general.

\section{A lack of unanimity}

The lack of unanimity about what constitutes a good education in journalism is evident in tertiary institutions around Australia. Universities offer journalism courses that vary widely in their subject offerings, structures and approaches. The membership of the Journalism Education Association (JEA) is drawn from 21 institutions around Australia, for example, while Putnis \& Axford (2002: 1) note that all but three major Australian universities offer degree programmes in Communication and Media Studies.

Putnis \& Axford refer to the paradox of diversity in conformity. They argue that the wide range of courses on offer is evidence of considerable curriculum innovation in direct response to industry needs; but on the other hand, the fact that there are so many courses suggests a pull towards what they call isomorphism - all the courses are starting to look alike. The problems with this, they say, are that individual institutions find it difficult to carve out niche markets that reflect their particular strengths; there is a lack of uniformity across the area of communication studies; and there is a lack of any means of measuring the quality of graduates. Henningham (1994: 89) says:

... Australia now has such a diverse range of programmes in what are collectively called 'journalism schools', that any common concept of journalism education has become meaningless. 
Henningham blames greedy universities that want to attract ever-increasing numbers of students, but do not want to invest in the quality of their journalism programmes. He compares such programmes to a hypothetical medical programme staffed by a single practitioner-lecturer teaching two one-semester subjects out of a Department of Biology, and claiming to qualify graduates to be practising doctors. This is a truly depressing view of professional education and, if somewhat overstated, it nevertheless serves to highlight the situation in some Australian university programmes.

To this scenario, let me add a university predilection to misunderstand journalism education and to equate it with education in other forms of communication. Journalism education is not like other communication subjects and it is especially not like other subjects outside the spectrum of mass media communication. Many communication core or theory subjects are especially amenable to being taught in lecture mode, supplemented with large seminars or workshops. Indeed, that is how we tend to teach them at the University of Canberra, and there is nothing wrong with that. But few journalism subjects lend themselves to such a mode of delivery because journalism education is an applied education. Students are involved in learning skills and drills, as well as the theory and context of journalism practice, and to do that they require smallclass attention from lecturers or tutors who are familiar with current industry practice. This means that each student requires at the very least a computer in the classroom, with internet connection, software that at least mirrors industry practice in a range of areas, telephones with long-distance access, and access to text and numerical databases. This makes teaching journalism an expensive business - more expensive than theory-based courses, and even more expensive again when taught in distance or flexible mode.

Yet journalism educators in many JEA institutions are coming under pressure to drop or amalgamate practical subjects, increase tutorial class sizes, and substitute lectures for tutorials. In some institutions, communication subjects are being offered as alternatives to journalism subjects in journalism courses where no such choice had existed before.

Henningham, urging journalism educators to 'bite the bullet' on standards of journalism education, proposed a 10-subject 'core' for journalism courses (1990: 89). Those 10 core subjects were: News Reporting \& Writing I, II and III; Sub-Editing and Production; Journalism Ethics; Journalism Law; Media Research Methods; Theories of News Media; International Media; and Journalism and Society. He saw these as the 10 essential journalism subjects in a 24-subject 
degree course. No doubt we can all construct our own lists of 10 core journalism subjects and many of them would mirror those proposed by Henningham.

Moves to drop journalism subjects are diametrically opposed to industry demand for better, more professional journalism graduates. If university courses are to produce such graduates, then journalism educators have to resist the desire of university administrators to reduce the per-student cost of journalism subjects. Educating journalists IS expensive and it requires provision of more infrastructure than other types of Arts/Social Sciences courses - and university administrations must be brought to recognise this. In Australia, at least, journalism graduates enjoy strong job outcomes and universities benefit from this in an environment where institutions are rewarded for achieving measurable outcomes - outcomes like good job success rates by journalism students.

I believe journalism educators have to fight for a fair share of the funds and prestige they bring in as a result of these outcomes. If journalism education is to have any effect on the practice of journalism — and clearly it should — then educators must show that an investment in a quality education is an investment in credibility and, at least according to the American Society of Newspaper Editor's research, a way to climb out of the circulation well.

\section{Solutions not entirely up to academy}

And yet, of course, the solution should not be left entirely up to the academy industry clearly has a vested interest in seeing universities produce well-trained, high quality graduates. Industry in Australia has a lamentable record of supporting journalism education and in this it merely reflects practice in most industries, outside the medical sphere. At my own university, the vice-chancellor has given notice that Australia's only conservator's degree, which has produced almost all of the professional conservators in the nation's museums, has become uneconomic and will have to close. Following public outrage and industry outcry over the axing of a nationally prestigious course, the vicechancellor appealed to industry for help to save it. Predictably, the response has been derisory and the course no doubt will close.

If the downward spiral in circulation and viewers is to stop, journalism education will play a large part in the battle against the decline. In doing so, it must arrive at a core curriculum that is supported not only by students and by industry, but that also has the support of university administrations and, even more importantly, is academically and pedagogically sound. The only way that 
can be achieved in Australia, I believe, is through a national system of accreditation that recognises a core of compulsory journalism content, but is flexible enough to allow universities to use the strengths and skills of individual staff members.

The (US) Accrediting Council for Education in Journalism and Mass Communication acknowledges the value of accreditation when it sets out the aims and missions of journalism in general and journalism education in particular. It says (www.ukans.edu/ acejmc/PROGRAM/PRINCIPLES.SHTML):

The mission of journalism and mass communications professions in a democratic society is to inform, to enlighten and to champion the freedoms guaranteed by the First Amendment. They seek to enable people to fulfill their responsibilities as citizens who mean to govern themselves. They seek to help people protect, pursue and promote their rights and interests in their personal lives and in their work in public and philanthropic service, in commerce and industry, and in the professions.

Professional programmes should prepare students with a body of knowledge and a system of inquiry, scholarship and training for careers in which they are accountable to:

- the public interest for their knowledge, ethics, competence and service;

- citizens, clients or consumers for their competencies and the quality of their work; and

- employers for their performance.

While academics acknowledge industry's requirements in journalism education (Herbert 2002; Smyth \& Lawe Davies 1990), industry alone should not be allowed to dictate what the content of a journalism course should contain. The ACEJMC notes:

The Council embraces the value of a liberal arts and sciences curriculum as the essential foundation for professional education in journalism and mass communications. Professional education applies the knowledge and perspectives of arts and sciences disciplines to the understanding of the modern world and to the evolution and workings of diverse communities within society.

An accreditation system should provide transparency of course offerings, allowing all stakeholders to see what is being offered and allowing them to make considered rather than subjective judgments; it also should encourage 
benchmarking among courses. If this is done properly and with appropriate input from all the stakeholders, then citizens will be better informed and the nation generally will be better off. A by-product will be at least a reduction in the angle of decline for newspaper readership and even, perhaps, a trend back upwards.

\section{Bibliography}

Accrediting Council on Journalism and Mass Communications www.ukans.edu/ acejmc/ (accessed 16 November 2002).

American Society of Newspaper Editors (1999) Journalism Credibility Project, www.asne.org/kiosk/reports/99reports/1999examiningourcredibility/ p108_About.html

Daniel, Ann (1990). Public Ratings of journalists. In Issues in Australian Journalism. John Henningham (ed.). Melbourne: Longman Cheshire.

Dickson, T. and Topping, E. (2001). Public Trust, Media Responsibility and Public Journalism: US Newspaper Educators' Attitudes About Media Credibility.

Green, Kerry Philip and Stephen McIlwaine (1999). Where Do All the Graduates Go? Australian Journalism Review, 21 (2): 134-41.

Henningham, John, (ed) (1990). Issues in Australian Journalism. Melbourne: Longman Cheshire.

Henningham, John (1994). A suggested core curriculum in journalism education. Australian Studies in Journalism, 16 (1): 88-93.

Herbert, John (2002). Just think of it as peer review: Industry accreditation will protect the future. Australian Journalism Review. 24 (2): in press.

Kirkpatrick, Rod (1996). Diploma to degree: 75 years of tertiary journalism studies. Australian Studies in Journalism, 3: 356-371.

O'Donnell, Penny (1999). The other 66 per cent? Rethinking the labour market for journalism graduates. Australian Journalism Review, 21 (1): 123-142.

Patching, Roger (1996). 900 into 300 won't go: Are Australia's journalism courses producing too many graduates? Australian Journalism Review, 18 (1): 53-66.

Putnis, Peter and Beverley Axford (2002). Communication and media studies in Australian universities: Diverse, innovative and isomorphic. Australian Journal of Communication, 29 (1): 1-20.

Roy Morgan Research Centre (2000). Nurses, Pharmacists And Doctors Most Respected Professions, Car Salesmen, Journalists And Real Estate Agents Least Respected, Finding No. 3349, November 2000. Available at www.roymorgan.com.au/polls/2000/3349/index.html 
Smyth, Chris and Chris Lawe Davies (1990). Education for professional journalists: A career path model, Bond University: JEA Conference.

Woolford, Don (1983). Journalism education: The Australian pattern Media Information Australia, 27: 40-43.

Dr Kerry Green is associate professor in the University of Canberra's School of Professional Communication. As outgoing president of the (Australian) Journalism Education Association, he presented this address, titled 'Journalism education: The need to synthesise industry-academy ambitions', at the Journalism Education Association of New Zealand (Jeanz) annual conference at Whitireia Community Polytechnic, Porirua, on 28-29 November 2002. Kerry.Green@canberra.edu.au 